\title{
A MOOC on universal design for learning designed based on the UDL paradigm
}

\author{
Liliana Herrera Nieves \\ University of Atlántico, Colombia \\ Emilio Crisol Moya \\ University of Granada, Spain
}

\section{Rosana Montes Soldado}

Andalusian Research Institute on Data Science and Computational Intelligence (DaSCI), University of Granada, Spain

\begin{abstract}
This article presents the design and pilot of an open online course, based on the principle of universal design for learning (Center for Applied Special Technology, 2011), to promote inclusive virtual education as an improvement transferable to other contexts. The course constitutes the first massive open online course (MOOC) training proposal of the University of Atlántico in Colombia. In this case study, we employed the instructional design methodology of analysis, design, development, implementation, and evaluation (Branch, 2009) and the universal design for learning guidelines. The design of this online training activity enhances the quality of inclusive virtual education, improves accessibility with no need for platform adjustments, and involves participants in their learning. This educational initiative complements the academic offer for students, graduates, administrators, teachers, and external guests, and contributes to the democratisation of education. The result is the creation of a MOOC, "Inclusive Educational Contexts: Design for all", which is accessible to a diverse range of learners.
\end{abstract}

Implications for practice or policy:

- With this MOOC, universities can translate the concept of inclusion to the academic community.

- Teachers may acquire competence in universal design for learning and evaluation of digital learning content with respect to usability, which would improve their virtual learning spaces.

- Information technology departments need to consider the importance of integrating assistive technologies into Moodle to improve the accessibility and usability of the platform itself.

Keywords: educational technology, inclusion, digital equity, instructional design, accessibility, usability, case study

\section{Introduction}

Talking about diversity in university classrooms requires orienting the organisation of the educational system, designing universal curricula, generating collaborative work among the entire academic community, and considering the environments in which the teaching-learning process is carried out.

It is important to offer quality education that facilitates learning based on pillars of universal accessibility (Quintana Püschel \& Martínez Angulo, 2014). Access to higher stages of education systems is increasingly encouraged, based on the processes of student orientation and expansion of educational provision (United Nations Educational, Scientific and Cultural Organization, 2008). As a consequence of this need, inclusive higher education, as a strategy for social inclusion, aims to create learning environments for all (Arizabaleta \& Ochoa, 2016).

According to the Ministry of National Education of Colombia (Ministerio de Educación Nacional, 2013), inclusive education is characterised by its social projection and interdisciplinary approach and attempts to facilitate the learning processes and the development of capacities and skills in the midst of diversity. To 
this end, institutions must promote inclusivity and knowledge integration within a new epistemological environment.

In the search for education for all, massive open online courses, or MOOCs, have revolutionised educational offerings. A MOOC is an open course with a learning-oriented structure and timing that leverage the Internet for global reach (Gea, 2016) and involves technological and pedagogical aspects in its development (Sarango-Lapo, Mena, \& Montoya, 2015). The essential elements of a MOOC are innovation, presentation of content through diverse sources, self-evaluation, motivation to create learning networks, and inspiration for the participants to be an agent of change in their own environments (Mailhes \& Raspa, 2015).

The University of Atlántico is located along the northern shore of Colombia. In 2009, the institute set up the Diverse Population Inclusion Program (DIVERSER) to strengthen the inclusion processes of students with disabilities in higher education. We have since developed a series of actions to enhance the academic offering, characterised by accessibility. A good example is the SICVI 567 platform (a Moodle environment), which has enabled the management of online courses, providing support for face-to-face education and making it easier for teachers to carry out academic and management-related tasks.

The major contribution of this research lies in the detailed description of the instructional design and application of the universal design for learning (UDL) principles and guidelines (Center for Applied Special Technology [CAST], 2011). The course is "Inclusive Educational Contexts: Design for all". It outlines the practical details for consideration when designing MOOCs, taking into account the diversity of participants, their learning styles, and interests. The pedagogical design of the MOOC is based on connectivism, emphasising digital and globalising learning, recognising that learning lies in a context where participants find in the platform a place to share previous experiences and be enriched by others. We have found MOOCs that focus on the theme of universal design as the central axis, as well as others that apply UDL in their design, but none that combine both elements.

\section{Literature review}

\section{Virtual educational environments: The Moodle platform at the University of Atlántico}

The major obstacles for higher education - authentic learning experiences and an advanced need to improve digital literacy - are considered to be solvable challenges; these are already being addressed by programs at individual institutions. Challenges we understand but whose solutions remain difficult to scale include advancing digital equity and adapting traditional organisational models to more flexible designs that advance the future of the workplace environment (Adams Becker et al., 2018).

People expect to be able to learn and work anywhere, with constant access to learning materials and to each other. Inclusive education implies meeting the needs of students with quality and equity. To personalise education, and guarantee the inclusion, access, attendance, participation, and evaluation of all members of society equally, we must take the time to consider equity and to ensure access to all the learning opportunities.

The role of education has been transformed through different paradigms that require the use of information and communication technologies (ICT). Universities have made great strides in generating more methods and platforms for faculty, students, and staff to collaborate and be productive wherever they are. E-learning is a modality that integrates educational and self-learning processes according to the needs of those involved (García-Peñalvo \& Seoane, 2015). E-learning enables the contextualisation of concepts such as learning styles and theoretical models to deliver more effective and personalised learning (Rodenes, Salvador, \& Moncaleano, 2013). Learning management systems (LMSs) are perfect for training activities tailored to a broader community that values diversity.

The advent of always-connected devices has provided more flexibility in how, when, and where people learn, and many institutions have updated their information technology (IT) infrastructure accordingly. But simply having a device that turns on and connects to the Internet is not sufficient. To enable success in learning requires digital equity as well. All aspects of the learning environment must be equally accessible and usable for all learners and instructors (Ambadkar, 2014). This includes considerations such as UDL, adaptive learning engagements, and overall affordability. 
LMSs are web-based systems that facilitate online communication, collaborative work, resource sharing, student assessment, and monitoring (Cassidy, 2016). When designing virtual courses in an LMS, you can focus on the student, highlighting their autonomy and self-regulation through the use of varied resources, and analysing their characteristics and learning styles. LMSs are expansive formative spaces that have gained strength in higher education. Human resources, such as a tutor who dynamises a forum, find tools in the LMS that enable them to involve apprentices in order for them to achieve active learning.

Given the existence of other platforms for MOOCs, such as Coursera, EdX or Udacity, the decision to develop the course in Moodle arose from the experience of the technical and pedagogical team in charge, and the possibilities given by the technological infrastructure at the University of Atlántico. Data shows that one of the most widely accepted open source platforms is Moodle (Matijašević-Obradović, Dragojlović, \& Babović, 2017), an acronym for modular object-oriented dynamic learning environment. As of October 2019, there are 106.650 registered sites in 230 countries, where Spain and Colombia are among the 10 countries that use it the most, as shown by the official figures on the Moodle website (Moodle, n.d.). To speak of Moodle means to recognise its free character to use it for any purpose, to adapt it to the needs of the owner, to distribute it, to improve the program, and to share those improvements (Llorente, 2007).

Moodle favours active learning and emphasises the role of the student in the whole process. The platform is supported by a large community of developers who contribute to its constant improvement and evolution. Moodle's modular character enables developers from all over the world to share their experiences and propose solutions. Plug-ins are a good example of developments which generate new functionalities and enhance the user experience. These modules increase Moodle's flexibility and are socialised through open forums (Costello, 2013).

Pedagogically, Moodle offers teachers autonomy, control, and monitoring of each person's work. Teachers can share files in formats such as text, audio, video, and links, configured according to users' needs (Conde Vides et al., 2016).

The University of Atlántico's Moodle platform is named SICVI 567. Figure 1 shows its runtime environment.

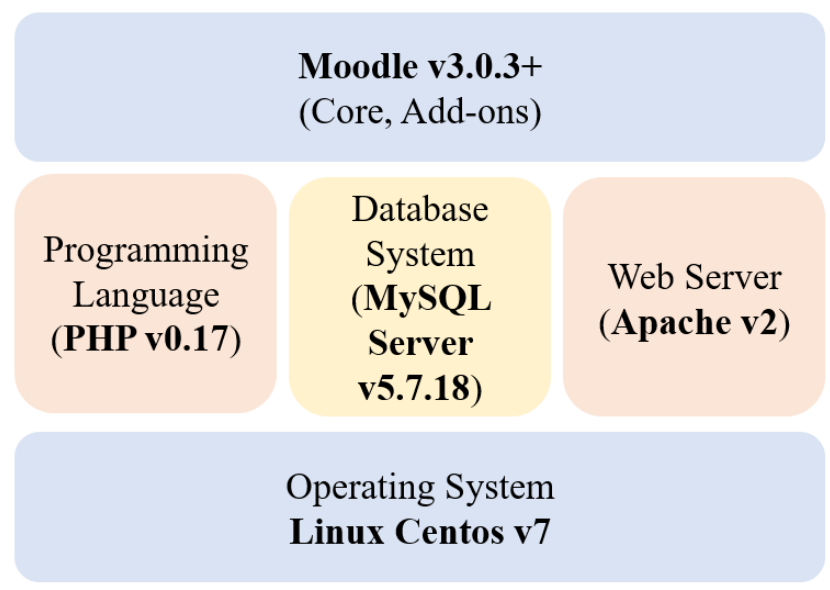

Figure 1. The environment where SICVI 567 Moodle platform runs

Plug-ins installed in Moodle include Grid Format 3.0.1, Essential template 3.0.1, and Simple certificate 2.2.6. 
Conceptually, courses in Moodle are organised according to the following modules (see Figure 2):

- Communication tools. A space containing the initial course agreements with a catalogue of tools that permit internal and external communication between students, teachers, advisors, and coordinators.

- Knowledge path. A space where participants can find the necessary content, resources, and study materials.

- Evaluation space. The environment containing the course activities or tasks.

- Support environment. The space which promotes the participants' contact with the main virtual resources and services offered by the University of Atlántico in the eCampus and its LMS.
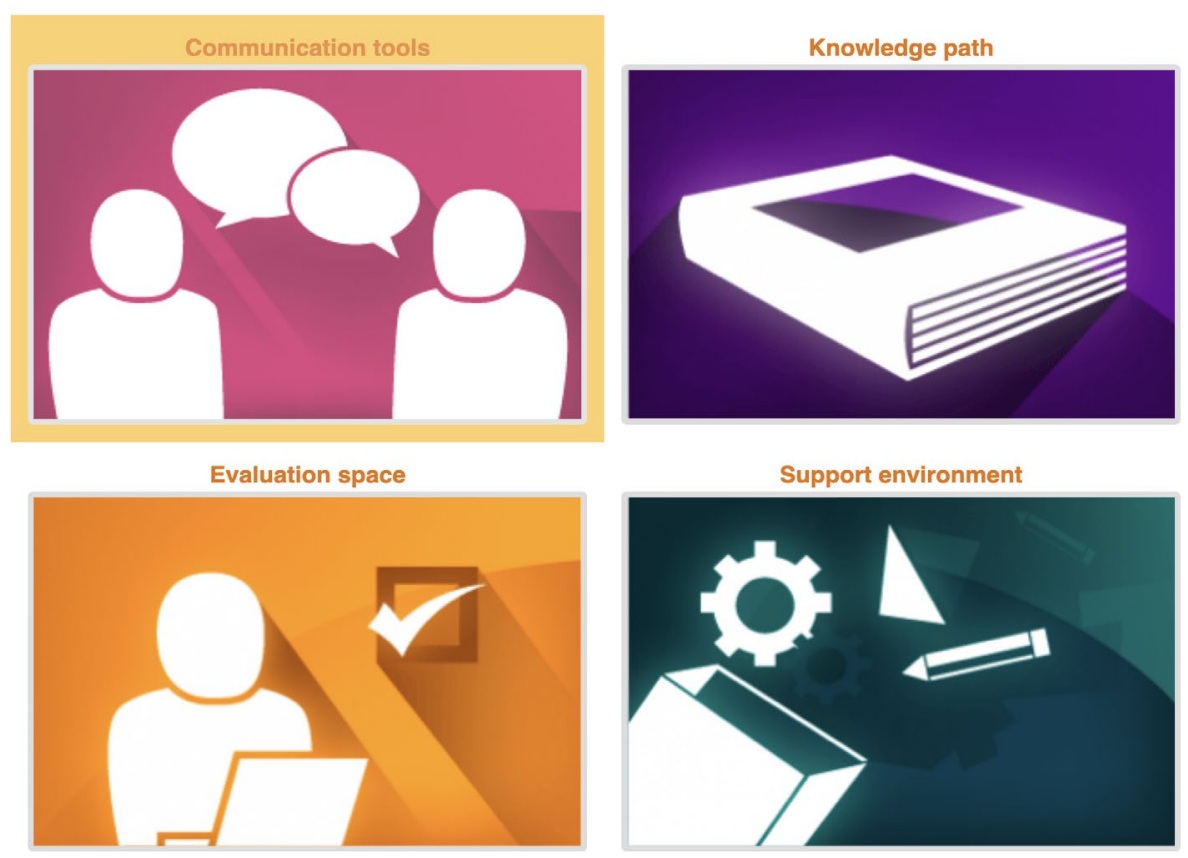

Figure 2. Environment for Moodle courses

The University of Atlántico has improved its infrastructure, creating the institutional conditions for integrating ICT. One of the tools provided is the SICVI 567 platform (Moodle). We are continuously working on its improvement, for example, its interface, task automation, and safety. In the near future, the institute plans to present the MOOC-UA platform, also based on Moodle for the distribution of MOOCs, in conjunction with the IT Department through the Virtual Education Project and supported by the Faculty of Education Sciences.

\section{Mass training}

The advent of MOOCs corresponds to an open learning movement that made an impact on society in 2012. MOOCs are a free distance learning option with a global reach, attractive audiovisual resources, and motivation techniques based on gamification and peer review (Gea, 2016).

The basis of MOOCs is that knowledge should be shared and accessible to all. These kinds of courses require a pedagogic transformation to virtual environments, incorporating new models and didactic strategies that promote inclusive education. The world's most prestigious educational institutes reaffirm MOOC experiences as innovative technologies that democratise education and create open learning communities (González, Del Pozo, Paredes, \& Del Pozo, 2018). That said, MOOCs suffer from massive dropouts and require new pedagogies, methodologies, and evaluations adapted to a massive scale (Loeckx, 2016), which is why this study is being presented. 
Massive online initiatives are managed under the MOOC concept, but with differences in methodology and applicability (Gea, Montes-Soldado, \& Rojas, 2013). MOOCs promote the importance of ubiquitous learning and can occur in any spatial and temporal environment. The fact that they are open is an advantage for access to education (Cano, Fernández \& Crescenzi, 2015). Open learning is a valuable strategy to improve the educational and cultural level of people and leads to the creation of learning communities (Calvo, Rodríguez, \& Fernández, 2016). The value of MOOCs is greatly enhanced through the use of social networks such as Twitter, which is why its use was considered for this project.

There are several MOOCs s about accessibility, design for all, and UDL, for example, those offered by the National Distance Education University in partnership with the Foundation for Cooperation and the Social Inclusion of the Disabled. Also noteworthy are those offered by Coursera, MiríadaX, and Open Education; all these show growing interest in the subject. A good practice is described in the design of "A MOOC for U”, at Iowa State University (Chatterjee, Juvale, \& Jaramillo Cherrez, 2017).

\section{UDL}

Humans are differentiated from other species by the way brain zones are activated during learning tasks. Brain variability determines different ways information is accessed, recognised, processed, and stored. In response to this diversity, CAST (2011) established the UDL approach.

UDL contributes to educational activities that guarantee the principles of equity and respect for diversity. In the "Convention on the Rights of Persons with Disabilities and Optional Protocol" - Article 2, the United Nations (2006) defined universal design as:

The design of products, environments, programmes and services to be usable by all people, to the greatest extent possible, without the need for adaptation or specialized design. 'Universal design' shall not exclude assistive devices for particular groups of persons with disabilities where this is needed. (p. 4)

UDL focuses on the design of flexible curricula, with diverse materials and means to provide everyone with learning. It is a didactic approach that applies the principles of universal design at any education level. UDL arose from research on neuroscience, education, and technology. It contains a series of principles and guidelines that address the needs of students. The three principles focus on providing multiple forms of representation, engagement, and action and expression, designed to lower curriculum barriers and maximise learning possibilities (Meyer, Rose, \& Gordon, 2014). The nine guidelines provide flexibility in disseminating information, reducing teaching barriers, providing adaptations and supports for learning, diversifying assessment methods, and keeping students committed to their learning (CAST, 2011). Scientific findings show that students who use accessible digital resources obtain better academic results, since analogue resources do not satisfy the needs of everyone (Sánchez \& Arathoon, 2016).

In virtual course design, it is paramount to ensure that everyone has access to and benefits from the services of the virtual platform and the course contents (García \& Ortega, 2010; Slater, Pearson, Warren, \& Forbes, 2015). According to Colombian Statutory Law 1618 of 2013 (Congreso de Colombia, 2013), accessibility is the "set of conditions and pertinent measures that information facilities and services must comply with to ensure access for persons with disabilities under equal conditions". The satisfaction and participation of all users of virtual services depends on the permanent study of accessibility and the application of its standards and guidelines (Morales, Fernández, \& Pulido, 2016). Usability is the degree of satisfaction and ease with which web resources are used. It is the capacity in which the platform can be understood, learned, used, and made attractive (ISO/IEC 25010, International Organization for Standardization, 2018) for people who access it in their different roles.

Accessibility and usability focus on the user experience, are closely related, and are important components for inclusive e-learning (González \& Farnós, 2009). The accessibility and usability of the content is related to the networks of representation and expression estimated by the UDL and help students define a range of learning paths or options by delivering multiple forms for learning and knowledge expression. Universal design in education requires a flexible curriculum, diversified practices, and different levels of student engagement, complexity, and expression (Alba, Sánchez \& Zubillaga, 2015; Morra \& Reynolds, 2010). UDL broadens the range of learning possibilities with the purpose of designing training in accordance with 
the needs of all the students and taking advantage of the affordances of technology (Rose \& Meyer, 2002), such as versatility, transformative capacity, and the generation of connections. The approaches proposed by UDL improve the adoption of online learning (Al-Azawei, Parslow, \& Lundqvist, 2017). In virtual courses, it is important to consider the factors that motivate enrolment and participants' attitudes in order to decrease dropouts (Hew \& Cheung, 2014).

Concepts such as accessibility, usability, and UDL have defined the material of our proposed MOOC and also have become the basis for its design. The challenge has been twofold: to reflect, synthesise, and transmit key concepts on universal design, and to apply the principles of UDL in the course design. Adopting a user-centred design and providing accessible learning resources are key to providing virtual education for all. MOOCs, given their massive and open character, offer potential for diverse learners, including people with functional diversity; hence the need to consider accessibility and user-centred design in the design of a MOOC (Rodríguez-Ascaso \& Boticario, 2015; Sánchez-Gordon \& Luján-Mora, 2016).

For this reason, this article intends to promote inclusive virtual education by presenting the design of a MOOC, as well as the design and results of its first delivery within the Moodle platform. This training activity, designed using the instructional model ADDIE (analysis, design, development, implementation and evaluation) (Branch, 2009) and UDL, is transferable to other online platforms and virtual courses.

\section{Methodology}

The methodology used is a case study, defined by Stake (1999) as a study about the complexity and particularity of a situation in certain circumstances or context. The case study is widely used in education, considering the classroom (face-to-face or virtual) as the setting where teachers and students participate in theorisation, reading, illustration, and dialogue about the phenomenon under study (Grandon Gill, 2011). The starting point of this work was the description of the participants' behaviour and their opinions on the use of UDL in the MOOC, without intrusion or alteration of the virtual context, thus fulfilling the role of observers. The authors, therefore, contributed to greater knowledge about inclusive virtual education and established guidelines for future studies.

In order to assess a possible transfer of experience and its application in other contexts, the following describes the information on the MOOC design process and the results obtained through a pilot test. Its purpose is to capture the practical details of the application of the UDL and how it promotes inclusive virtual education.

\section{Process}

The development of courses in virtual learning environments involves an exhaustive process that entails the planning and design of environments with the participation of an interdisciplinary group of professionals from technological and pedagogical fields. Through an instructional model, they create environments that facilitate the construction of knowledge.

The first version of "Inclusive Educational Contexts: Design for All" was open and online but limited to the University of Atlántico's community. This undertaking is linked to the university’s 2009-2019 strategic plan: "Humanistic and scientific training of excellence and relevance in undergraduate and graduate programs" and "Relations between university and society, linkage with the environment" (University of Atlántico, 2009, lines 2 \& 3).

The course is based on the ADDIE model (Branch, 2009). Instructional design articulates its technological and pedagogical dimension through the following phases and expected products (Aldoobie, 2015):

- Analysis. This initial stage defines the students' characteristics, available technical and pedagogical resources, budget-appropriate strategies, and the instructional objectives.

- Design. The pedagogical model is defined as well as the performance objectives and evaluation strategies. Focus is applied to evaluating the course content and choosing the appropriate format for information presentation. 
- Development. The learning strategies and materials are developed and a pilot is conducted from which relevant adjustments are defined.

- Implementation. The model and its procedures are rolled out with the participation of students and teachers. For this phase, three major steps are essential - training the instructors, preparing the learners, and organising the learning environment.

- beginning preparation by clarifying the methodology, the characteristics of the LMS, and expectations for the training activity.

- Evaluation. The criteria and tools are selected and employed to analyse the training results.

The ADDIE instructional model is widely used when designing virtual courses (Branch, 2009). It has been applied in educational experiences in Moodle, obtaining positive feedback from students (Nadiyah \& Shahbodin, 2015). Each stage is a flexible process, used to create products relevant to learning. Content is a key element, as participants of any virtual course spend most of their time studying autonomously (Wiphasith, Narumol, \& Sumalee, 2016).

In addition to the ADDIE model (Branch, 2009), we considered the accessibility and usability of the Moodle platform, along with its resources and activities. Both have been discussed in the design and development phases and research of Moodle, showing the importance of its accessibility and usability due to its versatility and configuration possibilities (Calvo, Iglesias, \& Moreno, 2013; González, Acosta, \& Moyares, 2010; Tapia-León, Palacios-Zamora, \& Luján Mora, 2016; Temesio, 2016). A course designed under the ADDIE model may not be fully accessible or usable, which is why these two features, so relevant to UDL, have been emphasised.

\section{Course description}

The 4-week MOOC pilot course took place between August and September of 2018. The pilot put into practice Moodle, keeping in mind the possibilities of a later evolution. This version of the course features an introductory unit with content organised in 3 modules, 42 educational resources in different complementary formats (audio, text, video), and 12 evaluation activities ( 6 mandatory and 6 optional). The design of the course suggests 25 hours of work on the part of the students. Participants who passed the course by carrying out the obligatory activities were awarded an online certificate free of charge.

The main topic of the MOOC is design for all and introduces participants to concepts such as diversity and its nuances in different social contexts, with an emphasis on education and current legal regulations. Subsequently, it enables the recognition of the paradigm of design for all, deepening the didactic approach of UDL and its relationship with technology. The information and resources are presented in various media (texts, audios, videos, videos interpreted in Colombian Sign Language). Also included are different types of activities that consider various levels of involvement, motivation, complexity, and expression, taking into account the principles of UDL, so that the course is useful for teachers and university students, especially for those whose main work is directly related to the design of products, environments, and services.

\section{Participants}

In the current academic semester (2019), the University of Atlántico has 1313 teachers, 25,000 students enrolled in 72 programs, and 59,692 graduates. All undergraduate programs have a virtual component to complement their traditional face-to-face academic and management activities. The use of Moodle incorporates e-learning and blended learning at the service of students and teachers.

The MOOC was publicised through massive institutional means, such as websites, email, and social networks in August 2018, one month prior to its launch. We had a form-based registration process, and on a voluntary basis, 806 people enrolled, of whom 520 actively participated in the course.

Administrative staff were invited to participate, given the importance of diversity awareness and design for all in each of the academic and alma mater management processes. On the other hand, the external guests were professors from national universities belonging to the Network of Universities for Disability in Colombia, from whom we hope to receive feedback on this first edition of the course, given their interest 
and trajectory in inclusive educational issues. The distribution of enrollees can be seen in Table 1. Given that this is our first MOOC, these figures highlight the strong participation of students and graduates. Future editions will have open enrolment, which should increase the number of participants.

Table 1

MOOC participants

\begin{tabular}{lll}
\hline Connection & Registered & Percentage \\
\hline Administrative staff & 31 & $6 \%$ \\
Teachers & 94 & $18 \%$ \\
Students & 192 & $37 \%$ \\
Graduates & 182 & $35 \%$ \\
Invitees & 21 & $4 \%$ \\
\hline Total & 520 & $100 \%$ \\
\hline
\end{tabular}

According to the ethical criteria of this research, participation was voluntary and the anonymity and use of the information for exclusively academic purposes have been ensured. Our students comprised 166 men and 354 women, 21 of whom had some sort of functional diversity ( 8 auditory, 1 physical, 8 visual, 2 psycho-social, and 2 suffering multiple conditions). Of the students, 50 had entered the educational system late; 30 had difficulties in mathematics, and 6 in reading and writing; 7 had attention deficit disorder with or without hyperactivity; and 1 had autism spectrum disorder. These results reflect a great diversity of learning styles and educational support needs.

\section{Data collection}

To validate our MOOC course design regarding aspects such as accessibility, usability, UDL, and usercentred design, two metrics were calculated. The first one was to run a usability test with two users, one of them with visual functional diversity. The second metric was obtained by means of the definition (and validation) of a questionnaire. The purpose of the questionnaire was to determine the opinion of the participants regarding the MOOC, which was designed under the principles of UDL. It served also to validate the design of the course with respect to user-centred design, UDL, accessibility, and usability. Usability attributes considered were learnability, efficiency, memorability, error prevention, and general satisfaction.

The questionnaire we designed consisted of 23 Likert scale questions with 5 options: totally in agreement, partially in agreement, indifferent, partially in disagreement, and totally in disagreement. The questions were organised into categories corresponding to the three UDL principles proposed by CAST in 2011: provide multiple means of representation, provide multiple means of action and expression, and provide multiple means of involvement. And in turn, items also reflected the nine guidelines that it comprises: to provide options for perception, to provide language options and symbols, to provide options for comprehension, to provide options for physical action, to provide options for expression and communication, to provide option for executive functions, to provide options for recruiting interest, to provide options for sustaining effort and persistence and to provide options for self-regulation.

The questionnaire was validated with the Delphi method by seven experts - teachers from the University of Atlántico (Colombia), the University of Granada (Spain), and the University of Guadalajara (Mexico). For the validation, the criteria of clarity, wording, presence, the scale used, and degree of importance were taken into account to assess the items. During the validation, two iterations were carried out, from which improvements were defined that enabled the development of the final version.

The evaluation of the students was conducted through a total of four questionnaires: a test for each module and a final test.

\section{Results}

Below, we present, in two sections, the results of applying the ADDIE (Branch, 2009) model and UDL in a virtual and open course. The first is related to the design of the course and the second is based on the 
results of the pilot. The importance of this course lies in its central theme and the way in which the resources and the Moodle platform have been employed.

\section{MOOC design}

The key components of the ADDIE model were observed in their phases with an emphasis on usability and platform accessibility.

Analysis phase

At this point, we set an objective to understand the value of human diversity and the importance of global design in environments that employ technologies that promote accessibility and usability and that favour inclusive education. The course demographic leverages social networks for publicity and information dissemination.

The human resources required were the LMS technical team, an advisor, virtual teachers and developers of educational resources, guest teachers, proofreaders, graphic designers, and audiovisual producers. A total of 37 people participated collaboratively in this project. As an added value, the experiences of the University of Granada's Digital Resource Production Center and the University of Atlántico's ITC Lab were taken into account. The university's standard technological resources were used, such as the Moodle, which enables the management of the virtual course and which has been configured taking into account UDL and accessibility features. Additionally, we considered it appropriate for a user of screen readers to conduct an evaluation of the system as an assistive technology (AT) for the visually impaired.

To make the course and its contents accessible, we followed the "Web Content Accessibility Guidelines" (World Wide Web Consortium, 2018), the "Authoring Tool Accessibility Guidelines" (World Wide Web Consortium, 2015), and the "Accessible Rich Internet Applications" versions 1.0 and 1.1 recommendations (World Wide Web Consortium, 2017). We employed each of the above to ensure all participants had access to the platform and its digital educational materials, including AT, such as screen readers, necessary for users with visual functional diversity. The Support Environment section of Moodle has a resources list regarding online AT, which helps participants (with or without functional diversity) with the virtual learning experience as these tools seek to improve the accessibility and usability of the platform. The flexible nature of the online methodology stands out throughout the course, considering individual and group activities, adjusted to the interests and time availability of the participants.

As the principles of UDL suggest, we used accessible resources by providing the same contents in multiple formats. This ensured that the contents are adjustable to the needs or preferences of the participants, whether or not they have a disability. In the activities, we also proposed that the participants could choose between multiple formats of expression to complete them.

The course is free of charge and does not involve any investment on the part of the participant; however, it does offer a certificate of recognition for a passing grade. The university obtains benefits not only by training its people (teachers, students, graduates, and administrative staff) but also in terms of strengthening of its image.

\section{Design phase}

In the design phase, which took place between October 2017 and June 2018, we carried out an inventory of tasks: planning, preparation, institutional budget approval, resource design, organisation of the virtual learning environment, characterisation of participants, dissemination of the MOOC, registration, enrolment, course development, follow-up tools, evaluation, and certification.

For the development of the course and its contents, there was voluntary participation from 23 teachers from Spain, Mexico, and Colombia, who recorded the audio and video lessons. The technical equipment for recording and editing the videos and audios and configuring Moodle and the virtual course required the support of the Digital Resource Production Center staff from the University of Granada and ITC Lab from the University of Atlántico. Furthermore, a Colombian Sign Language interpreter volunteered for the recording of the videos accessible to participants with auditory functional diversity. 
The design phase is relevant because it was necessary to consider the principles and guidelines of UDL, as well as accessibility and usability, to promote the interaction of participants with the platform and content, and to achieve the educational objectives. Based on the principle of multiple forms of representation, whose guidelines are intended to provide options for perception, language, symbols, and comprehension, the participants' performance objectives were defined and the contents of the course were designed. Resources included accessible PDF text, audios with subtitles, videos with subtitles, and videos with Colombian Sign Language interpretation (see Figure 3 ). This is what we mean by content in multiple formats. The purpose was to give the students the possibility of interacting with the contents in different modalities (Morra \& Reynolds, 2010). Participants in virtual courses recognise the benefits of using alternative formats, and although they use text, they prefer videos (Fidalgo \& Thormann, 2017), the latter being the most used resources in the form of video lessons (Calvo, Rodríguez, \& Fernández, 2016).

For this reason, we used resources with accessibility features to better present the content.

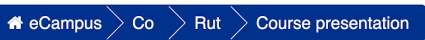

\section{Inclusive Educational Contexts: Design for all}

\section{Course presentation} On this page you will find all the resources related to the presentation of the course. Videos, documents and presentations that will help you understand the
methodology and how you can make the most of your learning experience.

Choose the format according to your preference:

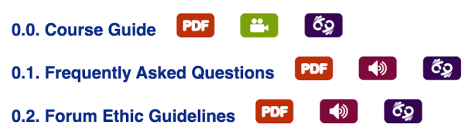

Figure 3. Resources in multiple formats identified with icons

In order for the user to become involved and familiar with the platform's standardised organisation in four environments, we provided a presentation section and a diagnostic strategy to get to know our participants better. This consisted of a self-evaluation test by the participants on their preferences for learning and expression styles (see Figure 4). With a total of 11 questions, we inquired about their preferences for receiving information, learning styles, diagnosis of functional diversity, and use of AT. In designing this questionnaire, some items enabled us to characterise the participants as well as their abilities (Alario-Hoyos, Estévez-Ayres, Pérez-Sanagustín, Kloos \& Fernández-Panadero, 2017). According to UDL, a person learns best when they self-reflect and receive tutoring, so if we also personalise that tutoring based on their learning style, we will develop more expert learning.

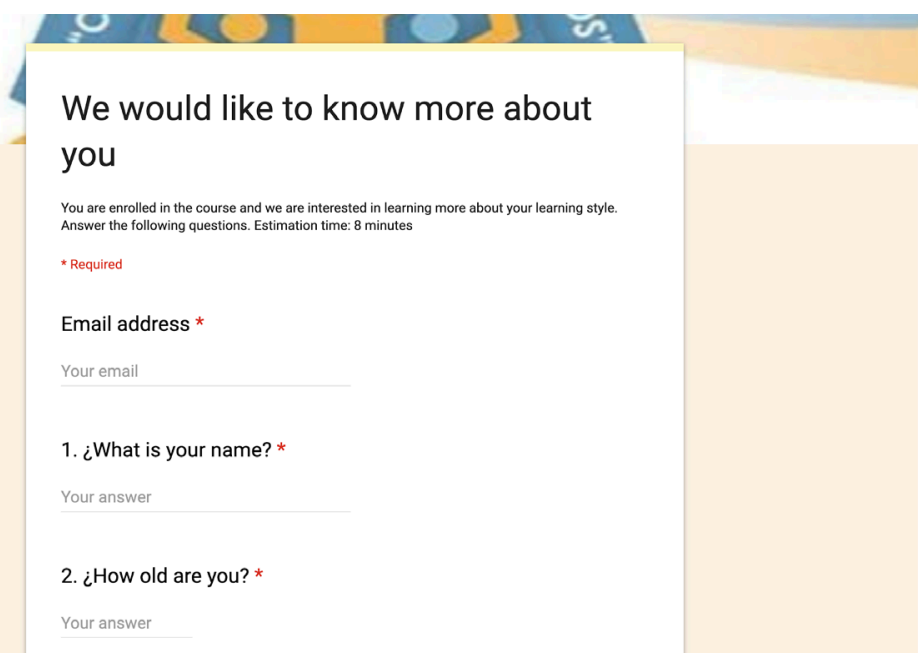

Figure 4. Google form set to acquire more information about the participants (translated from Spanish) 
To fully support the user, all of the following resources are offered: a glossary of key concepts, alternative text in images, graphics and labels on resources and activities, a description of icons and symbols used in the course, highlighted ideas and concepts, external links for complementary material, and to deepen understanding of topics, checkboxes to monitor the participant's progress, and a course calendar tool.

With respect to the principle of providing multiple means of action and expression, whose guidelines promote diverse forms of physical performance, expression skills, fluency, and executive function, different evaluation strategies were considered. When designing the virtual course, we took into account that the participant should recognise how they learn, identify their qualities, overcome their deficiencies and have the capacity to control cognitive processes, plan what they are going to learn, control and finally evaluate their achievements; that is to say, master their metacognition, known as the capacity to self-regulate their learning processes (Biggs \& Moore, 1993).

Each module has different activities, such as self-evaluation, forums, tests, and tasks, where the participant chooses between different forms of expression. The evaluation activities enable the participant to select the means of expression they prefer to use, for example, tag clouds, mind maps, concept maps, text writing, audios, videos, and drawings (see Figure 5). Having different options for conducting their activities is widely embraced by participants in online courses, as stated by Fidalgo and Thormann (2017), indicating that they prefer to use alternative media and that the freedom to select it opens up a range of possibilities and enables them to experiment with different formats.

\section{Activity 2. Reflect on diversity and choose how you express yourself}

\section{Activity 2. \\ To fulfill this activity, you must choose one of the three suggested options and make the delivery in the TASK link \\ OPTION 1 \\ Make a word cloud with the most important concepts learned in this first module. You can use an online tool like Tagxedo available at: http://www.tagxedo.com/. The file must be sent as a \\ HOMEWORK, in .pdf or .jpg format \\ OPTION 2 \\ Make an audio where you explain a brief conclusion about what has been learned in this module and how you think you can apply it to your personal life. \\ The file must be shared in the forum in audio format of maximum 60 seconds duration. You can use tools like https://soundcloud.com/ or https://www.youtube.com/ to share the audio \\ through a link. \\ OPTION 3 \\ Prepare a mind map that presents the relationship between the concepts given in this module. You can use a tool to make maps online, such as: https://wwwmindmeister.com/es or http://wisemapping.com \\ The file must be sent in the chosen format, whether you attach the file or share the link, by clicking the Add Task button. \\ Remember that you only have to make one of the three options and that you can choose according to your particular interests and previous knowledge in the use of these tools, or even your desire to learn a new one.}

Figure 5. The description of activities provides options for different ways of expression

Collaborative work is encouraged in the discussion forums on the most important topics of each module, generating collaborative learning. Students learn best when they interact not only with the teacher, but also with other online course participants (Rao \& Tanners, 2011).

It is important to recognise that connectivist learning is supported by several distributed technologies, including social networking (Wang, Anderson, \& Chen, 2018). In the course, Twitter has been used as an expression tool to create a sense of belonging to a learning community and to demonstrate what has been learned upon leaving the virtual classroom environment. Using Twitter increases social presence and sense of community among course participants (Rohr, Costello, \& Hawkins, 2015). The participants voluntarily used the social network Twitter as a means of expression external to Moodle, generating a total of 75 tweets, sharing text, images, and audios. We used the hashtags \#MoocDUA and \#InclusiveVirtualEducation.

Finally, in order to provide multiple forms of engagement, specifying different options for the search of interests, maintenance of effort, motivation, and self-regulation, the course provides contextualised, personalised and culturally significant information. The content is their own and with the participation of 
international teachers (from Spain, Colombia, and Mexico), a climate of support was established in the virtual classroom, where students receive feedback and checkboxes indicate the activities carried out to monitor their progress. The student has the possibility of selecting between different evaluation activities and proposals for flexibility to suit their individual schedules.

Gamification was employed by means of Moodle badges obtained by completing the self-evaluation questionnaires (see Figure 6). Each badge represents the successful completion of the three modules. After completing the activities in Module 1 and demonstrating an understanding of the concept of diversity, the participant earns the first badge. In order to obtain the second badge, the participant has to pass Module 2, on the theme of design for all. And the third is obtained by learning about technologies for all. On the other hand, the final badge is obtained at the end of the three modules of the course. Awarding badges for performing successful activities or tasks is a gamification technique. It is a form of feedback that indicates student progress, contributing to their motivation, while motivating them to participate (Pilkington, 2018).

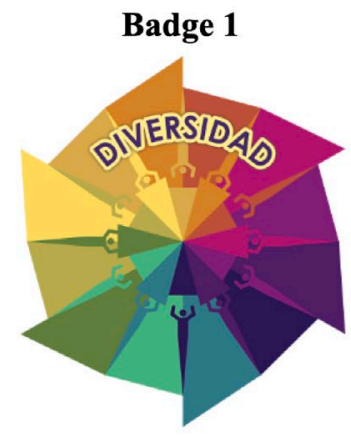

Badge 3

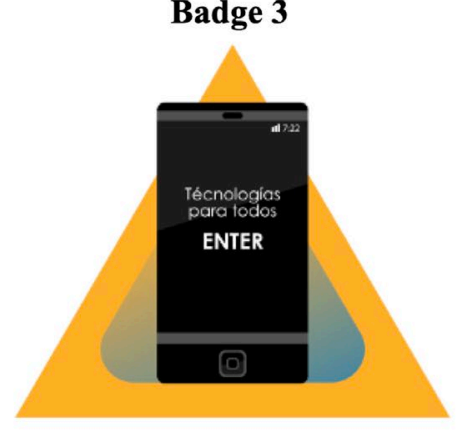

Badge 2

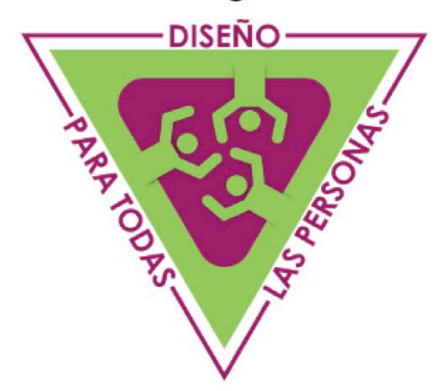

Final badge

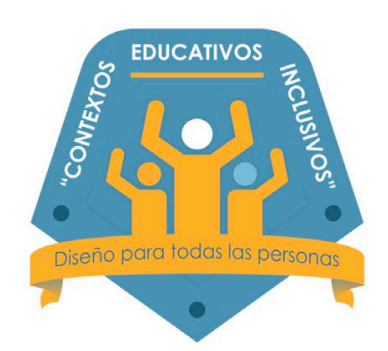

Figure 6. Course badges

Phases of development and implementation

In the development and implementation phases, officials from the Digital Resource Production Center of the University of Granada and the ITC Lab of the University of Atlántico participated in the recording and editing of the videos and audios. When the contents were defined, experts were selected to participate as guest lecturers in audio or video capsules. All resources are licensed under a Creative Commons Attribution-NonCommercial-NoDerivatives 4.0 International (CC BY-NC-ND 4.0) license: where the author allows copying, reproduction, distribution, and public dissemination of the work, so long as the original author is cited and recognised. It does not permit the generation of derivative works or their use for commercial purposes (Creative Commons, n.d.). The presentation formats of the resources we developed are subtitled videos, subtitled audios, texts in PDF, and videos employing Colombian Sign Language. Third-party online resources were also used.

To offer a clear guide on the methodology of the course, contents included:

- Course syllabus

- What do I need to know about the course before I start?

- What can I find in the virtual classroom?

- Frequently Asked Questions. 
There were two interactive spaces for participants to express their concerns: the Course Cafeteria Forum and the News Forum.

\section{Evaluation phase}

It was very important to evaluate the platform and the course during this phase. Therefore, once the course resources and platform configuration had been completed and prior to opening the course, a visually impaired teacher and a student using the Jaws screen reader performed a usability test to identify areas for improvement.

The didactic components for inclusive e-learning include participant motivation, learning methodologies, and pedagogical design, which consider varied evaluation systems (González \& Farnós, 2009). That is why we considered it essential to evaluate the course and not just the platform and asked for feedback from participants. The data collection instrument chosen was the questionnaire (23 items), designed with satisfaction criteria considering the attributes of usability and UDL. The questionnaire was used to evaluate the participants' experience with Moodle. It also incorporates a comparison of the experience in this MOOC with other courses hosted in Moodle.

\section{Results of the pilot test}

For this pilot experience, we invited volunteers from the pool of students, teachers, graduates, and officials from the University of Atlántico. Studies have concluded that participants sign up for MOOCs because of their desire to learn about a new topic or to extend their current knowledge of it, and also because they find this type of online training interesting and because they wish to receive a certificate (Hew \& Cheung, 2014).

MOOCs generally have low completion rates, with between $5 \%$ and $10 \%$ of enrollees achieving proficiency and certification (Gea, 2016). In our experience, however, 27\% of the 520 enrollees continued to course completion. We attribute these results to the elements considered in the course design and development, demonstrating that applying UDL principles and offering AT in virtual environments has a positive impact on results. One of the great challenges of MOOC courses is reducing dropouts through the implementation of new methodologies that lead to democratisation (Loeckx, 2016b). E-learning educational proposals favour self-learning and motivate participants according to their learning needs and styles (García-Peñalvo \& Seoane, 2015).

Generally, $90 \%$ of MOOC participants drop out because they lose interest, do not have incentives, do not understand the content, do not feel comfortable with the materials, do not receive feedback from teachers, and/or have other priorities (Hew \& Cheung, 2014). For that reason, an achievement of $27 \%$ of participants certified is significant.

Out of a total of 520 enrollees, 163 responded to the course-end evaluation. Of these, $90.8 \%$ fully agreed that the materials were accessible, while $8.6 \%$ partially agreed. We can conclude therefore that the considerations taken into account for the design of these resources were accepted by the participants. Accessibility and quality resources have been recognised as advantages of MOOC courses (Cano, Fernández, \& Crescenzi, 2015; Sánchez \& Arathoon, 2016). Providing accessible adjustments, not only to the content, but also to the platform, guarantees accessibility for all and provokes institutional awareness in the design of future training proposals (Slater, Pearson, Warren, \& Forbes, 2015). The latter is one of the aims of this research: to promote inclusive virtual education by raising awareness of universal design or design for all in the academic community.

Of the 163 participant answers, $87 \%$ fully agreed that they had the opportunity to activate prior knowledge; $85 \%$ agreed that they had a variety of learning strategies; $78 \%$ fully agreed and $21 \%$ partially agreed that they were able to achieve the objectives of the course; and $83 \%$ fully agreed and $15.3 \%$ partially agreed that they fulfilled their learning goals.

\section{Conclusions}

This experience recognises the importance of design for all in inclusive virtual education by incorporating UDL principles into course design and considering accessible resources. It is just as important to have universal and equal access to information as it is to provide citizens with the necessary skills to be able to 
analyse and reflect on what is being read, so that it does not remain merely an action of replicating information, but that information is in effect the basis for being able to transform the social and economic reality of individuals (Reich \& Ito, 2017). Instead of focusing on device access, this work addressed the necessary adjustments to content and community participation in the collective construction of knowledge, surrounding a topic that it is reflected in every human sphere, mainly education. The development of the course enabled participants and teachers to generate new learning that could be transferred to different contexts, seen from dissimilar perspectives.

Online training, including UDL, can minimise the need for refinements or adjustments for students with disabilities and be more accessible to all (Dell, Dell, \& Blackwell, 2015; Rao \& Tanners, 2011; Tobin, 2014;). One of the elements to be improved for future editions is to incorporate sign language interpretation in the description of all the resources. To enhance the value of the application of UDL in the virtual environment demands greater reflection when planning and specifying the training activity, because new scenarios and learning experiences must be contemplated, given the diverse characteristics of the participants. This favours inclusive virtual education, demonstrated in a MOOC-type experience that can be transferred to other contexts.

The use of multimedia resources is an effective and efficient way to provide information to the participants of an online course, favouring accessibility (Dell, Dell, \& Blackwell, 2015). These diverse formats can also be used by students to demonstrate their learning. Providing access to and encouraging the use of online AT that can be harnessed for expression through accessible multimedia content is an important element in recruiting participants' motivation (Scott \& Temple, 2017).

MOOCs represent a great learning opportunity for a variety of participants, so the design practices of this type of virtual course can be improved by considering UDL, accessibility, usability, and access to online AT. Our initiative not only encourages access to education for students with functional diversity, but also enhances the learning experience for all.

The great potential of educational technology to improve teaching and learning will only be realised if our educational technology efforts go hand in hand with a commitment to digital equity.

\section{Limitations and future research}

This MOOC pilot experience has been limited to the University of the Atlántico community. This restricted the scope of the MOOC; however, it will be enhanced in future experiences. We are currently working on the development of the technical capabilities of the MOOC-UA platform. When these are completed, this and other courses will be offered. Similarly, the study is a starting point for the improvement of the institutional virtual academic offer, as it brings knowledge to a diverse population.

\section{Acknowledgments}

This work was supported by the Spanish Ministry of Economy and Competitiveness under project TIN2017-89517-P.

Thanks are due to the 25 guest lecturers and the staff of the Digital Resource Production Center (University of Granada) and the Virtual Education Project (University of Atlántico) for their valuable contributions in bringing the course to light.

\section{References}

Adams Becker, S., Brown, M., Dahlstrom, E., Davis, A., DePaul, K., Diaz, V., \& Pomerantz, J. (2018). Horizon Report 2018: Higher education edition. Louisville, Co: EDUCAUSE. Retrieved from https://ibrary.educause.edu/ /media/files/library/2018/8/2018horizonreport.pdf

Alario-Hoyos, C., Estévez-Ayres, I., Pérez-Sanagustín, M., Kloos, C. D., \& Fernández-Panadero, C. (2017). Understanding learners' motivation and learning strategies in MOOCs. The International Review of Research in Open and Distributed Learning, 18(3), 119-117.

https://doi.org/10.19173/irrodl.v18i3.2996 
Al-Azawei, A., Parslow, P., \& Lundqvist, K. (2017). The effect of universal design for learning (UDL) application on e-learning acceptance: A structural equation model. The International Review of Research in Open and Distributed Learning, 18(6), 54-87. https://doi.org/10.19173/irrodl.v18i6.2880

Alba, C., Sánchez, J., \& Zubillaga, A. (2015). Tecnologías y Diseño Universal para el Aprendizaje (DUA): experiencias en el contexto universitario e implicaciones en la formación del profesorado [Technology and universal design for learning (UDL): Experiences in the university context and implications for teacher training]. RELATEC: Revista Latinoamericana de Tecnología Educativa, 14(1), 89-100. https://doi.org/10.17398/1695-288X.14.1.89

Aldoobie, N. (2015). ADDIE model. American International Journal of Contemporary Research, 5(6), 68-72. Retrieved from http://www.aijcrnet.com/journals/Vol 5 No 6 December 2015/10.pdf

Ambadkar, R. (2014). MOOCs: An aid for professional development of teachers in India. Global Online Electronic International Interdisciplinary Research Journal, 3(1), 91-96.

Arizabaleta, S., \& Ochoa, A. (2016). Hacia una educación inclusiva en Colombia [Towards an inclusive higher education in Colombia]. Pedagogía y Saberes, 45, 41-52. https://doi.org/10.17227/01212494.45pys41.52

Biggs, J. B., \& Moore, P. J. (1993). The process of learning. New York, NY: Prentice Hal.

Branch, R. (2009). Instructional design: The ADDIE approach. Athens, GA: Springer.

Calvo, A., Rodríguez, C., \& Fernández, E. (2016). ¿Cómo son los MOOC sobre educación? Un análisis de cursos de temática pedagógica que se ofertan en castellano [What are MOOCs on education like? An analysis of MOOCs on pedagogy offered in Spanish]. Digital Education Review, 29, 298-311. https://doi.org/10.1344/der.2016.29.298-311

Calvo, R., Iglesias, A., \& Moreno, L. (2013). Accessibility barriers for users of screen readers in the Moodle learning content management system. Universal Access in the Information Society, 13(3), 315-327. https://doi.org/10.1007/s10209-013-0314-3

Cano, M., Fernández, M., \& Crescenzi, L. (2015). Cursos en Línea Masivos y Abiertos: 20 expertos delinean el estado de la cuestión [Massive open online courses: 20 experts for a state of the art]. RELATEC: Revista Latinoamericana de Tecnología Educativa, 14(2), 25-37. https://doi.org/10.17398/1695-288X.14.2.25

Center for Applied Special Technology. (2011). Universal design for learning guidelines. Wakefield, MA: Author. Retrieved from http://udlguidelines.cast.org/binaries/content/assets/udlguidelines/udlgv2-0/udlg_graphicorganizer_v2-0.pdf

Cassidy, S. (2016). Virtual learning environments as mediating factors in student satisfaction with teaching and learning in higher education. Journal of Curriculum and Teaching, 5(1), 113-123. https://doi.org/10.5430/jct.v5n1p113

Chatterjee, R., Juvale, D., \& Jaramillo Cherrez, N. (2017). A MOOC for U: The design of a MOOC based on universal design for learning. In P. Resta \& S. Smith (Eds.), Proceedings of the Society for Information Technology \& Teacher Education International Conference (pp. 143-148). Chesapeake, VA: Association for the Advancement of Computing in Education. Retrieved from https://www.learntechlib.org/primary/p/177560/

Conde Vides, J., García Luna, D., García Rodríguez, J., Hermiz Ramírez, A., Moreno López, J. J., Muñoz Solís, P. L., \& Osorio Navarro, A. (2016). Manual Moodle 3.0 para el profesor [Moodle manual 3.0 for teachers]. Retrieved from http://serviciosgate.upm.es/docs/moodle/manual_moodle 3.0.pdf

Congreso de Colombia. (2013). Ley estatutaria 1618 [Statutory law 1618]. Retrieved from http://wsp.presidencia.gov.co/Normativa/Leyes/Documents/2013/LEY\%201618\%20DEL\%2027\%20 DE\%20FEBRERO\%20DE\%202013.pdf

Costello, E. (2013). Opening up to open source: Looking at how Moodle was adopted in higher education. Open Learning: The Journal of Open, Distance and e-Learning, 28(3), 187-200. https://doi.org/10.1080/02680513.2013.856289

Creative Commons. (n.d). Attribution-NonCommercial-NoDerivatives 4.0 International (CC BY-NC-ND 4.0). Retrieved from https://creativecommons.org/licenses/by-nc-nd/4.0/

Dell, C., Dell, T., \& Blackwell, T. (2015). Applying universal design for learning in online courses: Pedagogical and practical considerations. Journal of Educators Online, 12(2), 166-192. Retrieved from https://www.thejeo.com/archive/2015 12_2/dell_dell_blackwell

Fidalgo, P., \& Thormann, J. (2017). Reaching students in online courses using alternative formats. The International Review of Research in Open and Distributed Learning, 18(2), 139-161. https://doi.org/10.19173/irrodl.v18i2.2601 
García, M., \& Ortega, I. (2010). Atención a la e-accesibilidad y usabilidad universal en el diseño formativo [Attention to e-accessibility and universal usability in training design]. Pixel-Bit. Revista de Medios y Educación, 36, 89-99. Retrieved from http://www.redalyc.org/pdf/368/36815128007.pdf

García-Peñalvo, F., \& Seoane, A. (2015). Una revisión actualizada del concepto de elearning. Décimo aniversario [An updated review of the concept of eLearning: Tenth anniversary]. Education in the Knowledge Society, 16(1), 119-144. https://doi.org/10.14201/eks2015161119144

Gea, M. (2016). Para qué sirve un MOOC: Reflexión sobre la evolución del aprendizaje digital. In M. Gea (Ed.), Experiencia MOOC: un enfoque hacia el aprendizaje digital la creación de contenidos docentes y comunidades online [MOOC experience: An approach to digital learning, the creation of educational content and online communities] (pp. 11-22). Granada, Spain: EUG.

Gea, M., Montes-Soldado, R., \& Rojas, B. (2013). Cursos masivos mediante la creación de comunidades activas de aprendizaje [Massive courses through the creation of active learning communities]. Trabajo presentado en XV Simposio Internacional de Tecnologías de la Información y las Comunicaciones en la Educación (pp. 21-28). Retrieved from http://adie.es/static_adie/SINTICE13-ActasCongreso.pdf

González, A., \& Farnós, J. (2009). Usabilidad y accesibilidad para un e-learning inclusivo [Usability and accessibility for inclusive e-learning]. Revista de Educación Inclusiva, 2(1), 49-60. Retrieved from http://www.revistaeducacioninclusiva.es/index.php/REI/article/view/26

González, A., Acosta, Y., \& Moyares, Y. (2010). Propuesta de un manual de usabilidad y accesibilidad para el desarrollo de personalizaciones de la plataforma de teleformación Moodle [Proposal of a usability and accessibility manual for the development of customizations of the Moodle tele-training platform]. Revista Electrónica de Tecnología Educativa, 34, 151-164. Retrieved from https://www.edutec.es/revista/index.php/edutec-e/article/view/425/161

González, S. G., Del Pozo, F., Paredes, W., \& Del Pozo, H. (2018). Los MOOC: tecnología y pedagogía emergente para la democratización del conocimiento [The MOOC: Emerging technology and pedagogy for the democratization of knowledge]. Revista Perspectiva, 19(2), 215-224. Retrieved from http://revistas.upagu.edu.pe/index.php/PE/article/view/584

Grandon Gill, T. (2011). Informing with the case method: A guide to case method research writing, \& faciliation. Santa Rosa, CA: Informing Science Press.

Hew, K. F., \& Cheung, W. S. (2014). Students' and instructors' use of massive open online courses (MOOCs): Motivations and challenges. Educational Research Review, 12, 45-58. https://doi.org/10.1016/j.edurev.2014.05.001

International Organization for Standardization. (2018). ISO 9241-11: 2018 (en) - Ergonomics of humansystem interaction - Part 11: Usability: Definitions and concepts. Retrieved from https://www.iso.org/obp/ui/\#iso:std:iso:9241:-11:ed-2:v1:en

Llorente, M. (2007). Moodle como entorno virtual de formación al alcance de todos [Towards e-learning from free software: Moodle like a Learning Managament System (LMS) within reach of all]. Comunicar Revista Científica de Comunicación y Educación, 28, 197-202. https://doi.org/10.3916/C28-2007-20

Loeckx, J. (2016). Blurring boundaries in education: Context and impact of MOOCs. The International Review of Research in Open and Distributed Learning, 17(3), 90-121 https://doi.org/10.19173/irrodl.v17i3.2395

Mailhes, V., \& Raspa, J. (2015). MOOC: De la revolución educativa a la supervivencia. Letra. Imagen. Sonido [MOOC: From educational revolution to survival]. Ciudad Mediatizada, 14, 75-91. Retrieved from https://publicaciones.sociales.uba.ar/index.php/lis/article/view/3805/3130

Matijašević-Obradović, H., Dragojlović, J., \& Babović, S. (2017). The importance of distance learning and the use of Moodle educational platform in education. In Proceedings of Sinteza 2017: International Scientific Conference on Information Technology and Data Related Research (pp. 236241). https://doi.org/10.15308/Sinteza-2017-236-241

Meyer, A., Rose, D., \& Gordon, D. (2014). Universal design for learning: Theory and practice. Wakefield, MA: Center for Applied Special Technology.

Ministerio de Educación Nacional. (2013). Politica de educación superior inclusiva [Inclusive higher education policy]. Retrieved from http://www.dialogoeducacionsuperior.edu.co/1750/articles327647 documento tres.pdf

Moodle. (n.d.). Moodle statistics. Retrieved October 31, 2019, from https://moodle.net/stats/ 
Morales, J., Fernández, K., \& Pulido, J. E. (2016). Evaluación de técnicas de producción accesible en cursos masivos, abiertos y en línea - MOOC [Evaluation of techniques for accessible production in massive, online, open course - MOOC]. Revista CINTEX, 21(1), 89-112. Retrieved from https://revistas.pascualbravo.edu.co/index.php/cintex/article/view/11/11

Morra, T., \& Reynolds, J. (2010). Universal design for learning: Application for technology-enhanced learning. Inquiry: The Journal of the Virginia Community Colleges, 15(1), 43-51. Retrieved from https://commons.vccs.edu/cgi/viewcontent.cgi?article=1030\&context=inquiry

Nadiyah, S., \& Shahbodin, F. (2015). The development of online project based collaborative learning using ADDIE Model. Procedia - Social and Behavioral Sciences, 195, 1803-1812. https://doi.org/10.1016/j.sbspro.2015.06.392

Pilkington, C. (2018). A playful approach to fostering motivation in a distance education computer programming course: Behaviour change and student perceptions. International Review of Research in Open and Distributed Learning, 19(3), 281-298. https://doi.org/10.19173/irrodl.v19i3.3664.v19i3.3664

Quintana Püschel, M., \& Martínez Ángulo, C. (2014). Programas de inclusión de personas en situación de discapacidad en la Universidad de Los Lagos, Chile [Programs for the inclusion of people with disabilities at the University of Los Lagos, Chile]. Revista Inclusiones, 1(3), 105-118. Retrieved from http://www.archivosrevistainclusiones.com/gallery/7\%20oficial\%202014\%20jul\%20sep $\% 20 \mathrm{rev} \% 20 \mathrm{i}$ nc.pdf

Rao, K., \& Tanners, A. (2011). Curb cuts in cyberspace: Universal instructional design for online courses. Journal of Postsecondary Education and Disability, 24(3), 211-229. Retrieved from http://www.aheadarchive.org/uploads/publications/JPED/jped_24_3/JPED\%2024_3_FULL\%20DOC UMENT.pdf

Reich, J., \& Ito, M. (2017). From good intentions to real outcomes: Equity by design in learning technologies. Irvine, CA: Digital Media and Learning Research Hub. Retrieved from https://clalliance.org/wp-content/uploads/2017/11/GIROreport_1031.pdf

Rodenes, M., Salvador, R., \& Moncaleano, G. (2013). E-learning: características y evaluación [Elearning: Characteristics and evaluation]. Ensayos de economía, 23(43), 143-159. Retrieved from https://revistas.unal.edu.co/index.php/ede/article/viewFile/42932/44359

Rodríguez-Ascaso, A., \& Boticario, J. (2015). Accesibilidad y MOOC: Hacia una perspectiva integral [Accessibility and MOOC: Towards a holistic perspective]. RIED: Revista Iberoamericana de Educación a Distancia, 18(2), 61-85. Retrieved from http://espacio.uned.es/fez/view/bibliuned:revistaRied-2015-18-2-7030

Rohr, L. E., Costello, J., \& Hawkins, T. (2015). Design considerations for integrating Twitter into an online course. The International Review of Research in Open and Distributed Learning, 16(4), 241249. https://doi.org/10.19173/irrodl.v16i4.2376

Rose, D.H., \& Meyer, A. (2002). Teaching every student in the digital age: Universal design for learning. Alexandria, VA: Association for Supervision and Curriculum Development.

Sánchez, J., \& Arathoon, A. (2016). Recursos digitales y Diseño Universal de Aprendizaje. En C. Alba (Ed.), Diseño Universal para el Aprendizaje: Educación para todos y prácticas de enseñanza inclusiva [Digital resources and universal design for learning] (pp. 89-122). Madrid, Spain: Ediciones Morata.

Sanchez-Gordon, S., \& Luján-Mora, S. (2016). How could MOOCs become accessible? The case of edX and the future of inclusive online learning. Journal of Universal Computer Science, 22(1), 55-81. Retrieved from http://jucs.org/jucs_22 1/how_could_moocs_become/jucs_22_01_0055 0081_gordon.pdf

Sarango-Lapo, C., Mena, J., \& Montoya, M. (2015). Prácticas Educativas Abiertas: experiencias de innovación en una institución de educación superior del Ecuador [Open educational practices: Experiences of innovation in a higher education institution in Ecuador]. Virtualis, 6(12), 218-234. Retrieved from https://www.revistavirtualis.mx/index.php/virtualis/article/view/138

Scott, L., \& Temple, P. (2017). A conceptual framework for building UDL in a special education distance education course. Journal of Educators Online, 14(1). Retrieved from https://www.thejeo.com/archive/archive/2017 141/jeo a conceptual framework for building udlpd $\underline{f}$

Slater, R., Pearson, V., Warren, J., \& Forbes, T. (2015). Institutional change for improving accessibility in the design and delivery of distance learning: The role of faculty accessibility specialists at The Open University. Open Learning: The Journal of Open, Distance and e-Learning, 30(1), 6-20. https://doi.org/10.1080/02680513.2015.1013528

Stake, R. (1999). Investigación con estudio de casos [Case study research]. Madrid, Spain: Morata. 
Tapia-León, M., Palacios-Zamora, K., \& Luján Mora, S. (2016). Propuesta de una guía para un curso virtual en Moodle sobre creación de contenidos educativos accesibles [Proposal for a guide for a virtual Moodle course on the creation of accessible educational content]. Revista Inclusiones, 3(3), 168-181. Retrieved from http://rua.ua.es/dspace/handle/10045/58536

Temesio, S. (2016). Educación inclusiva: Retos y oportunidades. Revista de Educación a Distancia, 51(9), 1-26. https://doi.org/10.6018/red/51/9

Tobin, T. (2014). Increase online student retention with Universal Design for Learning. Quarterly Review of Distance Education, 15(3). 13-24. Retrieved from http://mathcs.duq.edu/ tobin/cv/QRDE.UDL.Article.pdf

United Nations. (2006). Convention on the rights of persons with disabilities and optional protocol. Retrieved from https://www.un.org/disabilities/documents/convention/convoptprot-e.pdf

United Nations Educational, Scientific and Cultural Organization. (2008). La educación inclusiva: el camino hacia el futuro [Inclusive education: The way of the future]. Geneva, Switzerland: Author. Retrieved from http://www.ibe.unesco.org/fileadmin/user_upload/Policy_Dialogue/48th_ICE/General_Presentation48CIE-4 Spanish .pdf

University of Atlántico. (2009). Plan Estratégico Institucional 2009-2019 [Institutional strategic plan 2009-2019]. Retrieved from https://www.uniatlantico.edu.co/uatlantico/pdf/arc 5016.pdf

Wang, Z., Anderson, T., \& Chen, L. (2018). How learners participate in connectivist learning: An analysis of the interaction traces from a cMOOC. The International Review of Research in Open and Distributed Learning, 19(1). 44-66. https://doi.org/10.19173/irrodl.v19i1.3269

Wiphasith, H., Narumol, R., \& Sumalee, C. (2016). The design of the contents of an e-learning for teaching M.5 English language using ADDIE model. International Journal of Information and Education Technology, 6(2), 127-131. https://doi.org/10.7763/IJIET.2016.V6.671

World Wide Web Consortium. (2015). Authoring tool accessibility guidelines (ATAG 2.0). Retrieved from https://www.w3.org/TR/ATAG20/

World Wide Web Consortium. (2017). Accessible rich internet applications (WAI-ARIA 1.1). Retrieved from https://www.w3.org/TR/wai-aria/

World Wide Web Consortium. (2018). Web content accessibility guidelines (WCAG) overview. Retrieved from https://www.w3.org/WAI/standards-guidelines/wcag/

Corresponding author: Emilio Crisol Moya, ecrisol@ugr.es

Copyright: Articles published in the Australasian Journal of Educational Technology (AJET) are available under Creative Commons Attribution Non-Commercial No Derivatives Licence (CC BY-NC-ND 4.0). Authors retain copyright in their work and grant AJET right of first publication under CC BY-NC-ND 4.0.

Please cite as: Herrera Nieves, L., Crisol Moya, E., \& Montes Soldado, R. (2019). A MOOC on universal design for learning designed based on the UDL paradigm. Australasian Journal of Educational Technology, 35(6), 30-47. https://doi.org/10.14742/ajet.5532 